\title{
Palaeogeography of Atlantic Canadian Continental Shelves from the Last Glacial Maximum to the Present, with an Emphasis on Flemish Cap
}

\author{
John Shaw \\ Geological Survey of Canada (Atlantic), Bedford Institute of Oceanography \\ P. O. Box 1006, Dartmouth, Nova Scotia, Canada B2Y 4A2
}

Shaw, J. 2006. Palaeogeography of Atlantic Canadian Continental Shelves from the Last Glacial Maximum to the Present, with an Emphasis on Flemish Cap. J. Northw. Atl. Fish. Sci., 37: 119-126. doi:10.2960/J.v37.m565

\begin{abstract}
Flemish Cap is a fragment of continental crust detached from related terranes in Europe and Ireland by crustal spreading and stretching over the last $150 \mathrm{Ma}$. It has a core of basement rocks (chiefly Hadrynian granite) surrounded by younger sedimentary rocks. Since the last glacial maximum the geography of the surrounding shelves has changed due to glacial eustatic and isostatic processes. Glacier ice reached the edge of the continental shelves in most areas at its maximum extent. The ice retreated by calving in deeper water, with accelerated calving of the Gulf of St. Lawrence beginning just before $14 \mathrm{ka}$ BP (radiocarbon years). By $13 \mathrm{ka}$ BP ice was largely confined to land areas. An archipelago on the outer shelf, from Grand Bank to the continent, persisted from $>13 \mathrm{ka}$ BP until c. $8 \mathrm{ka} \mathrm{BP}$. Flemish Cap was probably not glaciated, although it was - and continues to be - impacted by icebergs. It was probably not emergent, although it was impacted by high wave energy during sealevel lowering. In comparison with the more 'hostile' glacial and ice-proximal environments along the shelf edge from southern Labrador to New England Flemish Cap was a relatively benign shallow-water environment with hard substrates, and may be a suitable candidate for a glacial marine refugium.
\end{abstract}

Key words: Flemish Cap, glaciation, palaeogeography, refugium

\section{Introduction}

It has long been understood that the environments on the continental shelves surrounding Atlantic Canada are relatively recent. This understanding is based on the knowledge that much of the region was ice-covered at the last glacial maximum (LGM). Mix et al. (2001) define LGM as "the most recent interval when global ice sheets reached their maximum integrated volume during the last glaciation", and argue that it probably took place between 19.5 and $15 \mathrm{ka}$ BP (radiocarbon years before present, where present is defined as $1950 \mathrm{AD}$ ). The particular questions that are of interest to biologists relate to the potential for glacial refugia for plants and animals, and to the routes by which they may have migrated into Atlantic Canada and the adjacent shelves after retreat of the ice. This paper explores changes in geography that took place since LGM that result from: 1) changes in the distribution of glacier ice; and 2) changes in relative sea level - caused by melting of glacier ice, crustal motions, and other factors. The study area is Atlantic Canada, and extends from Flemish Cap in the east to the head of the St. Lawrence estuary in the west, and from southern Labrador to a latitude just south of Cape Cod, USA.

\section{The Continental Shelves in the Study Area}

The morphology of the study area (Fig. 1) has considerable bearing on the questions being discussed, particularly the behavior of glacier ice. The continental shelves are dissected by over-deepened channels that must have been formed by a mechanism other than river erosion (King et al., 1974). The Laurentian Channel (Fig. 1) is more than $500 \mathrm{~m}$ deep in some areas, and shallows at the shelf edge to a depth of $410 \mathrm{~m}$. Off the northeast coast of Newfoundland, the continental shelf is deeper than elsewhere, as are the offshore banks, (e.g. Funk Island Bank, 220-300 m). Trinity Trough and Notre Dame Channel (Fig. 1) (Warren, 1976) extend to the shelf edge. Farther north, on the Labrador Shelf, deep troughs (Figs. 1 and 2) intersect the offshore banks and extend to the shelf edge (Josenhans et al., 1986; Josenhans and Fader, 1989). Off Nova Scotia, Emerald Basin and LaHave Basin are the largest of a series of irregular basins on 
the shelf. In the Gulf of Maine, over-deepened basins converge into the Northeast Channel that shallows to a shelf-edge depth of $200 \mathrm{~m}$. The deepest water landward of the shelf edges is not in the basins noted above, but in the fiords that radiate from the interior of Newfoundland (Shaw, 2003). Those on the west coast are moderately deep (230 m maximum). The southwest coast fiords are commonly several hundred metres deep, although one fiord has a maximum depth of $770 \mathrm{~m}$. Maximum depths in northeast coast fiords commonly exceed $600 \mathrm{~m}$.

\section{Flemish Cap}

Flemish Cap is an isolated offshore bank located east of the Grand Banks of Newfoundland, with a least depth of $126 \mathrm{~m}$. It is separated from the Grand Banks by the Flemish Pass, that is more than a thousand metres deep. Flemish Cap is the easternmost part of the continental crust of North America (Shrivastava and Verhoef, 1992; Shrivastava et al., 2000; Todd and Reid, 1989). About $118 \mathrm{Ma}$ it lay in proximity to North Africa, Europe and Greenland, and became separated with the advent of a long period of ocean spreading and crustal extension that continues today. The innermost core of Flemish Cap, an oval-shaped region measuring $70 \mathrm{~km} \times 100 \mathrm{~km}$, comprises acoustic basement rocks, specifically Hadrynian granite, granodiorite, acid and basic volcanics, and sandstone, siltstone and slate (King et al., 1985). The sea floor is rugged, with local topographic relief of tens of metres. The surrounding areas - generally below a depth of $200 \mathrm{~m}$ - are floored by Cretaceous and Tertiary sedimentary rock, strongly deformed in some areas but less so in others. In both regions, there are discontinuous and thin Quaternary deposits. In all areas, however, the seafloor is, in geological terms 'hard', consisting of bouldery gravel to coarse sand, and is heavily imprinted by iceberg pitting and scours dating from the last glacial period to the present (King et al., 1985).

Several previous reconstructions of palaeogeography are noteworthy. Bousefield and Thomas (1975) produced maps showing the 'Physical-Climatic Situation' in Atlantic Canada at 15.0, 12.5, 9.5, 7.0, 5.0 and $3.0 \mathrm{ka} \mathrm{BP}$. The maps show emergent areas on the shelves. Extensive emergent areas at $15.0 \mathrm{ka}$ BP gradually reduced in size and extent through time. The authors discuss the migration of biota, and explain the dislocated warm-water fauna in the southern Gulf of St. Lawrence caused by retreat from a mid-Holocene climatic optimum.

Dyke and Prest's (1987a, b) maps show ice margins at or near modern coasts from LGM until $14 \mathrm{ka} \mathrm{BP,} \mathrm{af-}$ ter which retreat began. This model has been challenged in recent decades (Dyke et al., 2002) as new data have become available from shelf areas and as the practice of radiocarbon dating bulk samples has been replaced by the AMS method. In a recent paper (Shaw et al., 2006) we argue that the glaciers reached the shelf edges in most areas, and that the retreat was a complex process whereby the ice sheet collapsed because of the actions of ice streams and iceberg calving.

The changes in relative sea level that are depicted in the reconstructions above are caused by meltwater release, by crustal motions caused by loading/unloading of both ice and meltwater, and other effects. The modeling approach to these processes is epitomized by the various manifestations of R.W. Peltier's geodynamic models (e.g. Peltier, 2002a, b; 2004). An alternative approach is to reconstruct the ancient geography using empirical data. Using this approach Shaw et al. (2002) deduced the distribution of land and sea in Atlantic Canada from $13 \mathrm{ka} \mathrm{BP}$ until the present day in one millennium increments. The reconstructions only go as far back as 13 ka BP because sea-level index points, commonly derived from shells deposited at the marine margins of ice sheets, are sparse beyond that date (in other words, ice cover was too extensive to leave a record).

The goals of this paper are therefore:

- To examine the geography of the continental shelves of Atlantic Canada during the last glaciation to determine whether or not Flemish Cap was glaciated.

- To determine if Flemish Cap was subaerially exposed as a result of lowered relative sea level.

\section{Methods}

Shaw et al. (2002) describe a method whereby they reconstructed the palaeogeography of Atlantic Canada since $13 \mathrm{ka}$ BP (radiocarbon years). They compiled published relative sea-level curves from which they derived relative sea-level values for 1000-year intervals from $13 \mathrm{ka}$ to $6 \mathrm{ka} \mathrm{BP}$. Isobase maps were derived from plotted relative sea-level data, and were digitized and rendered into grids using the GRASS geographic information system running in a UNIX environment. Shaw et al. (2002) built a modern digital elevation model (DEM) with a grid resolution of $788 \mathrm{~m}$ (the DEM is now available as a GSC Open File Report: Shaw and Courtney, 2004). The isobase surfaces were subtracted from the modern DEM in GRASS to produce palaeo-elevation models. The choice of $6 \mathrm{ka}$ and $13 \mathrm{ka} \mathrm{BP}$ as limits for the reconstructions was based on several factors. First, changes after $6 \mathrm{ka}$ are rather difficult to discern at the 


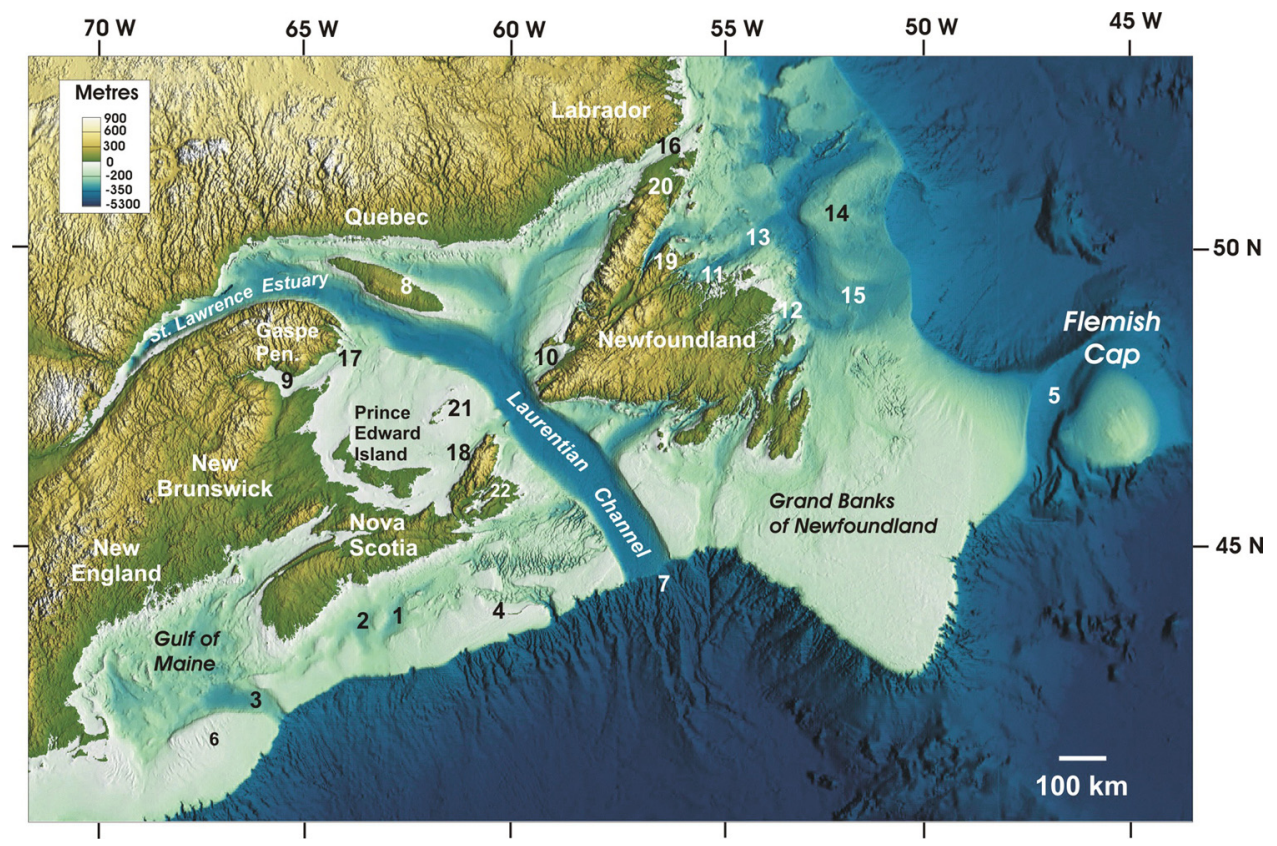

Fig. 1. Shaded relief image of Atlantic Canada and the adjacent continental shelves. This is an eastward extension of the digital elevation model used by Shaw et al. (2002) to reconstruct palaeotopography. The original digital elevation model is available as a GSC Open File Report (Shaw and Courtney, 2004). Numbered locations are as follows: 1) Emerald Basin; 2) LaHave Basin; 3) Northeast Channel; 4) Sable Island Bank; 5) Flemish Pass; 6) Georges Bank; 7) Laurentian Fan; 8) Anticosti Island; 9) Chaleur Bay; 10) St. George's Bay; 11) Notre Dame Bay; 12) Bonavista Bay; 13) Notre Dame Channel; 14) Funk Island Bank; 15) Trinity Trough; 16) Strait of Belle Isle; 17) Chaleur Trough; 18) Cape Breton Trough; 19) Baie Verte Peninsula; 20) Great Northern Peninsula; 21) Magdalen Islands; 22) Cape Breton Island.

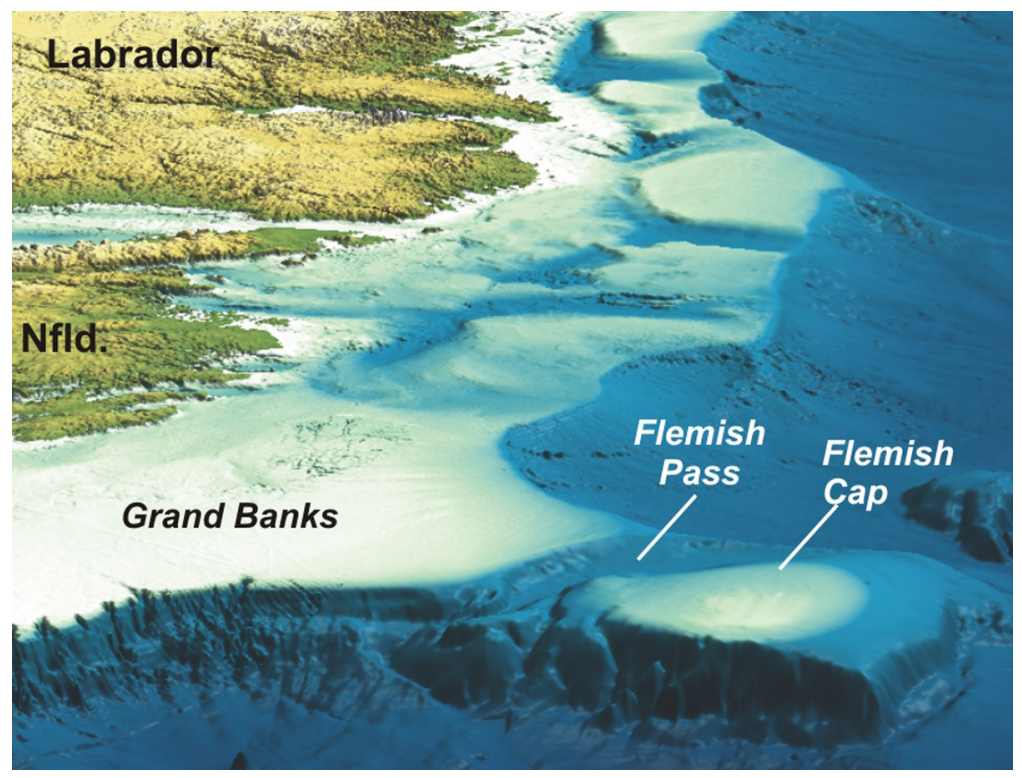

Fig. 2. 3-D view of Flemish Cap from the south. The deep shelf-crossing troughs off Labrador appear in the distance. The relatively Shallow Flemish Cap is separated from the Grand Banks of Newfoundland by Flemish Pass, which has depths in excess of $1000 \mathrm{~m}$. 


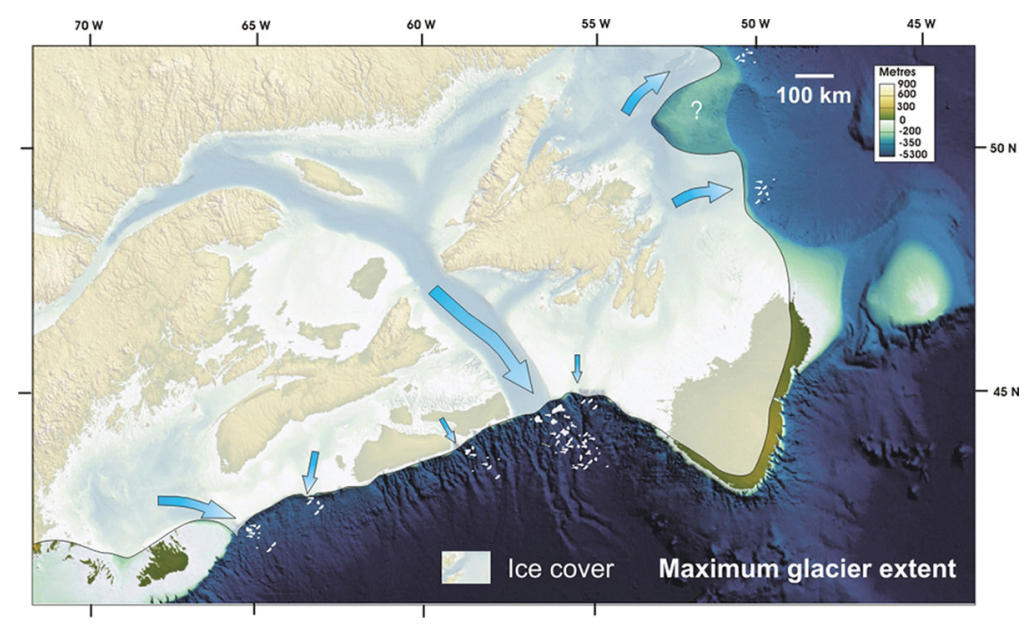

Fig. 3. Distribution of glacial ice at the last glacial maximum. Small areas of the Grand Banks remained unglaciated and are above sea level (green colour). Flemish Cap is unglaciated and is below sea level. Blue arrows indicate distribution and estimated relative size of ice streams.

Fig. 4. 13 ka BP palaeogeography. Large marine areas of Atlantic Canada are ice free by this time, but glaciers remain on most land areas. Several ice caps exist on the Grand Banks. The outer Grand Banks and large areas of the Scotian Shelf are above sea level (green colour).
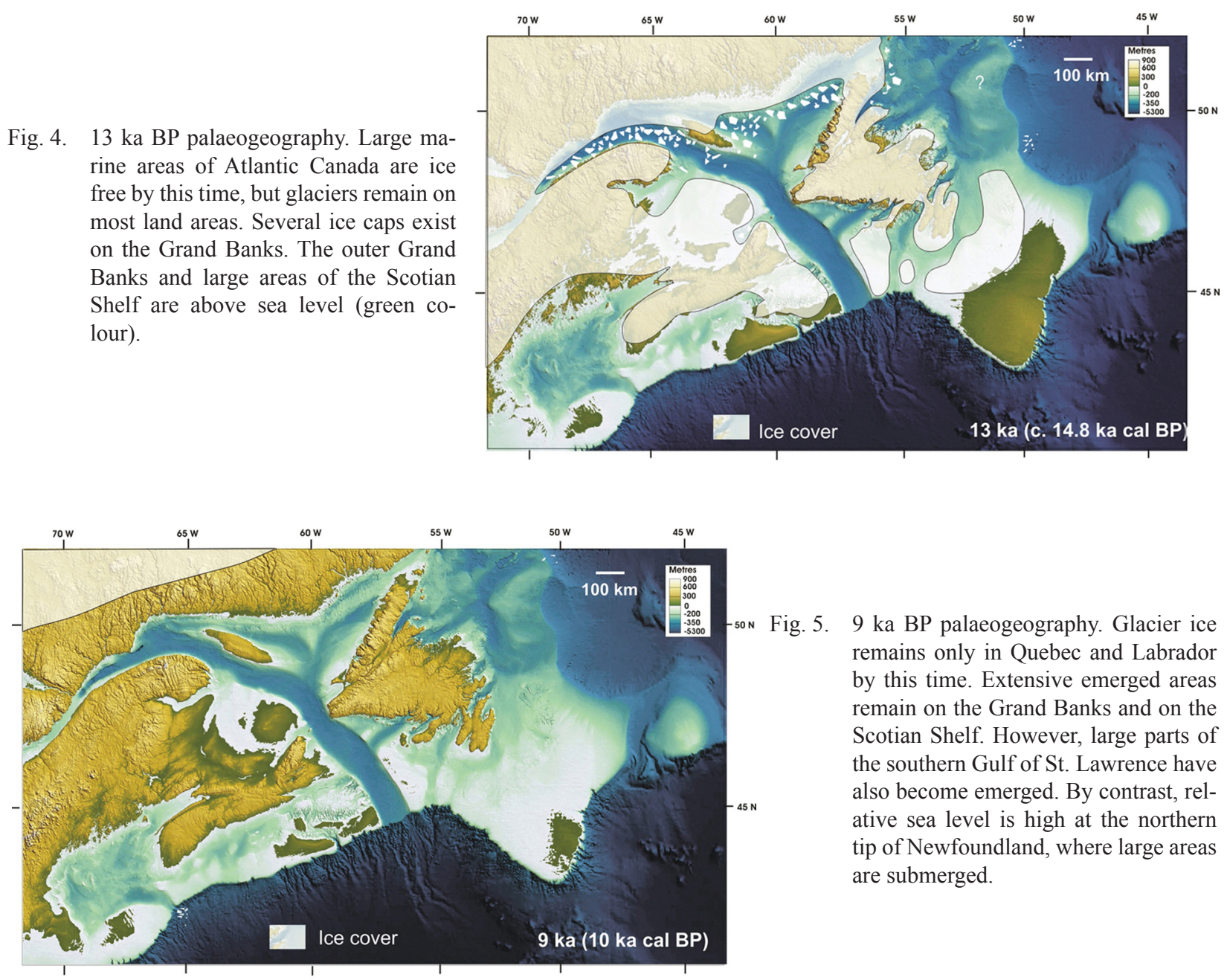

Fig. 5. 9 ka BP palaeogeography. Glacier ice remains only in Quebec and Labrador by this time. Extensive emerged areas remain on the Grand Banks and on the Scotian Shelf. However, large parts of the southern Gulf of St. Lawrence have also become emerged. By contrast, relative sea level is high at the northern tip of Newfoundland, where large areas are submerged. 
scales of the maps. Second, there is a paucity of relative sea-level index points earlier than c. $13 \mathrm{ka}$ BP because many coastal regions were covered by glacier ice.

Dyke and Prest's (1987a,b) ice margins were superimposed on the Shaw et al. (2002) maps. Dyke and Prest's map shows that the continental shelf was unglaciated at the last glacial maximum: the ice margin lay near the modern coasts of Atlantic Canada. However, in the past few decades the weight of evidence from investigations on the continental shelves of the region has supported the concept that during the Wisconsinan glacial period glaciers reached the edge of the continental shelf in most areas (see e.g. Dyke et al., 2002). In a recent paper (Shaw et al., 2006) we present a conceptual model of ice cover at the last maximum and at subsequent stages. Those ice margins are used in this paper.

Several problems arose when applying this methodology to Flemish Cap. Firstly, the DEM used by Shaw et al. (2002) did not extend as far east as Flemish Cap. We remedied this by extending the DEM eastward and recalculating palaeo-topography. Secondly, there existed no empirical relative sea-level data for Flemish Cap. To remedy this deficiency ICE-5G predictions are used when discussing relative sea level and potential for emergence at various times. The underlying DEM in the LGM reconstruction shown in Figure 3 is that for $13 \mathrm{ka} \mathrm{BP}$, the oldest palaeo-topography available to us (because of an absence of empirical data). The $13 \mathrm{ka}$ BP DEM provides a reasonable approximation of the extent of subaerial areas at the margins of the ice sheets at LGM.

Our results are cited in terms of thousands of radiocarbon years before present (ka BP) where present is defined as 1950. The radiocarbon timescale increasingly diverges from the sidereal timescale beyond about $7 \mathrm{ka} \mathrm{BP}$.

\section{Results}

\section{The Last Glacial Maximum (LGM)}

The ice-sheet margins reached the continental shelf edge throughout the region shown in Figure 3, except in the west where the margin on Georges Bank was terrestrial. The structure of the ice sheets was complex in that a series of major divides separated catchment areas that were, periodically or intermittently, drained by ice streams that discharged water, sediment and ice to the ocean. The major ice streams are shown in Figure 3. In our paper (Shaw et al., 2006) we argue that the margin depicted here existed before the classic LGM, perhaps as early as $25 \mathrm{ka}$ BP (see also Piper and Campbell, in press). The ice margin comprised two principal types: 1) a limited number of active ice streams, located in deep, shelf-crossing troughs; and 2) relatively inactive ice that nevertheless was grounded to depths of 450-500 m on the Scotian shelf (Mosher et al., 1989; Bonifay and Piper, 1988). The continental slope experienced active debris flows that radiated out from the ice margin, and the entire ice margin was characterized by turbid plumes. In our reconstruction Flemish Cap (Fig. 1) does not support an ice sheet, and is distant from the ice-sheet margins that exist elsewhere.

Figure 3, based on the 13 ka DEM, shows that Flemish Cap is submerged. It is necessary to confirm that this is the case at LGM. There are no empirical data for the area, so we must rely on the predictions of R.W. Peltier's ICE-5G model. A relative sea-level (rsl) curve for the area shows a typical outer shelf curve, with rsl falling until c. $17 \mathrm{ka} \mathrm{BP}$, then rising rapidly after c. $13 \mathrm{ka} \mathrm{BP}$. The lowest sea level for the area is $-116 \mathrm{~m}$ at c. $17 \mathrm{ka} \mathrm{BP}$. Given the minimum present day water depth of $126 \mathrm{~m}$, this implies that the bank was about $10 \mathrm{~m}$ below sea level when relative sea level in the area was at its lowest.

\section{The Deglaciation Process}

This process is discussed at length by Shaw et al., (2006) who argue that deglaciation proceeded by the calving of grounded ice in deep water. This began on the continental shelf off northeastern Newfoundland, and then continued in the Gulf of Maine. On the continental shelf off Nova Scotia the removal of grounded ice was underway in the Emerald Basin by $18 \mathrm{ka}$ BP. Although margins retreated in these deep-water areas over many thousands of years, the calving ice margin at the end of the ice stream in the Laurentian Channel maintained its position at the edge of the continental shelf, at the Laurentian Fan, until just after 14.5 ka BP, when it started to retreat (Piper and Macdonald, 2001).

The retreat of the calving margin to the northwest in the Laurentian Channel was rapid, as shown by the maps of Josenhans and Lehman (1999). The Laurentian Moraine, dated at $13.7 \mathrm{ka}$ by King and Fader (1990) and subsequently at $14.3 \mathrm{ka}$ BP by Josenhans and Lehman (1999), indicates that the calving margin was south of the Cabot Strait at that time. King and Fader (1990) also showed that the moraine extends down either side of the Laurentian Channel, along the flanks of the banks. The glacier ice remaining on the banks formed till tongues that interfinger with glaciomarine sediments in the Laurentian Channel. The embayment rapidly retreated northwest into the Gulf of St. Lawrence. Rodrigues et al. (1993) reported that open water existed in the channel between Anticosti Island and the Gaspe Peninsula by $14040 \pm 240$ BP. The calving embayment reached near 
the head of the St. Lawrence Estuary, by 13.5 ka BP (Locat, 1977). The calving evidently reached the head of Chaleur Bay by $13890 \pm 160$ BP (date by Lebuis and David, 1977, cited by Rodrigues et al., 1993).

By $14 \mathrm{ka}$, the removal of ice by calving in deep channels had started the process of isolating an ice cap on Newfoundland; the rapidly calving ice margins had reached the south and southwest coasts of the island (Shaw et al., 2000; Shaw, 2003). Calving halted at the tidewater margin in St. George's Bay (Bell et al., 2001; Liverman and Bell, 1996). Shaw (2003) showed strong difference in ice drainage along several coasts of the island, reflecting morphologic control. The St. George's Bay ice margin was fed by convergent flow into the lowlands from a relatively large catchment. Along the south coast of Newfoundland, following the removal of ice from the deep water immediately offshore, ice was channeled into a series of relatively small fiords, each outlet receiving ice from a relatively small catchment. The fiord-mouth calving margins are distinguished by prominent fiord-mouth moraines that date as early as $14.2 \mathrm{ka}$ BP (Shaw et al., 2002). On the northeast Newfoundland coast (Notre Dame Bay) the ice did not halt in its retreat because the fiord sills were too deep or non-existent.

The major calving event underway at $14 \mathrm{ka}$ removed ice from deep channels on the west side of the Grand Banks, isolating and creating an ice cap on the Grand Banks. Calving along deep channels either side of the lobate Newfoundland Ice Cap margin also isolated smaller ice caps. Removal of ice from Bonavista Bay by $13.5 \mathrm{ka}$ (Cumming et al., 1991) confirms that the major calving episode of $14 \mathrm{ka}$ also happened in that area. In Notre Dame Bay, there are no dates as early as $14 \mathrm{ka}$ $\mathrm{BP}$, suggesting that the calving margin in the bay lay just offshore, probably grounded on the flanks of the deep (>400 m) Notre Dame Channel and forming the moraines described by Shaw (2003).

\section{Geography at 13 ka BP}

This period (Fig. 4) represents an interesting phase in the deglaciation process. In the earlier phase, from the maximum until just c. 13 ka BP, retreat was by calving. Also, large volumes of ice were being delivered to the ocean by ice streams, even when they were not retreating. From c. 13 ka onwards, most (but not all) glacier ice was on land, and ablation of the ice sheets proceeded by melting and sublimation alone (Shaw et al., 2006).

In the Gulf of Maine, ice had retreated inland of the present coast, and the margin was either terrestrial or tidewater, depending on local relief. Relative sea levels were high, except in the south, where low relative sea level had exposed a greater extent of Georges Bank than before (Shaw et al., 2002). In the Gulf of St. Lawrence the calving margin had migrated far up the St. Lawrence Estuary, and lay near the Strait of Belle Isle in the northeast. After 13.9 ka BP tributary ice streams readvanced down the Chaleur and Cape Breton Troughs. Josenhans and Lehman (1999) chronicled several readvances down Cape Breton Trough from $13.5 \mathrm{ka}$ to $13.2 \mathrm{ka} \mathrm{BP}$, and depicted an advance down Chaleur Trough at $13.2 \mathrm{ka} \mathrm{BP}$.

Along the west coast of Newfoundland, ice originating on the ice cap on Newfoundland was discharging into the Gulf of St. Lawrence via fiords, forming calving piedmont lobes that, with falling relative sea level, soon retreated inland (Shaw, 2003). Along the south coast, ice draining from the interior was being discharged at fiord mouths, with the numerous 'jets' of high-velocity ice being separated by wide ice-free interfleuves. By $12.5 \mathrm{ka}$ BP these margins had retreated to fiord heads.

Calving retreat along deep channels, and ablation on land had now formed three isolated ice masses on the continental shelf off Newfoundland. In northeast Newfoundland a major lobe was mostly on land and was slowly ablating, although high relative sea level resulted in marine margins in some areas. To the west, the margin in Notre Dame Bay was mostly terrestrial, and was also retreating by ablation. A lobe on Baie Verte Peninsula remained, and a tidewater margin extended along the east side of the Great Northern Peninsula.

Because of low relative sea level, parts of the offshore banks were emergent, forming islands, the largest of which occupied Grand Bank (Fig. 4). On the continental shelf off Nova Scotia the offshore banks were emergent, forming a chain of islands. Georges Bank was also an island, and there were some smaller islands between there and the mainland. In New England and New Brunswick there was significant submergence of low-lying coastal regions, forming embayments that penetrated far inland along modern river valleys. In the Gulf of St. Lawrence, a large emerged area surrounded the modern Magdalen Islands. Relative sea level was rising slowly on the submerged Flemish Cap at $13 \mathrm{ka} \mathrm{BP}$, at which time according to ICE-5G relative sea level at Flemish Cap lay between -111 and $-106 \mathrm{~m}$.

\section{Geography at 9 ka BP}

The large island on the Grand Banks (Fig. 5) was smaller than at $13 \mathrm{ka}$. The islands in the vicinity of Sable Island Bank were smaller in extent, or had broken into several parts due to submergence. Georges Bank was similarly reduced in extent. The emergent areas around Prince Edward Island, the Magdalen Islands, and Cape 
Breton Island had reached their greatest extent. A wide peninsula extended northeast into the Gulf of St. Lawrence from western Prince Edward Island, and a similar peninsula extended from northeastern New Brunswick. In Newfoundland there were small areas of emergence in the southwest - the St. George's Bay area. The northern tip of the Great Northern Peninsula remained submerged, except for a large island. The coastal fringe of the mainland (south Labrador and Quebec) was also submerged.

Relative sea level was now rising rapidly on Flemish Cap. ICE-5G shows a value of relative sea level between -52 and $-57 \mathrm{~m}$. The water depth at the shallowest point on Flemish Cap was in the range 69 to $74 \mathrm{~m}$.

\section{Subsequent Changes}

Relative sea-level rise became pervasive after $9 \mathrm{ka} \mathrm{BP}$ in most southern areas. The islands on the continental shelves were greatly reduced in size by $8 \mathrm{ka}$ BP and disappeared soon afterward. A major change took place c. 6 ka BP when Prince Edward Island formed due to rising relative sea level. Ongoing research shows that the ocean flooded across a sill at $25 \mathrm{~m}$ below modern sea level around 6.0 ka BP, and created the Bras d' Or Lakes - the inland sea on Cape Breton Island. In Newfoundland, as relative sea level rose, a series of deltas at the heads of fiords in south and east Newfoundland were submerged (Shaw and Forbes, 1995).

\section{Discussion}

Since the original publication of palaeogeographic maps (Shaw et al., 2002) scientific interest has come from several sources. Most interest has been shown by biologists anxious to understand the history of stocks such as Atlantic salmon, Atlantic Cod, and freshwater fishes. The maps offer an explanation for possible glacial refugia for some species, or explain the migration of other species (freshwater fishes) into the region following ice retreat and climate warming.

During the last glacial maximum, large ice streams were active in the deep troughs that cross the shelves, including the Laurentian Channel and the deep troughs off northeast Newfoundland. Between the calving margins of the ice streams, ice either reached the shelf edges, and was grounded to depths of up to $500 \mathrm{~m}$ or so, or was separated from the shelf edges by a narrow strip of emerged land. The entire margin experienced turbid sediment plumes, while the continental slopes were characterized by debris-flow activity. However, Flemish Cap was not glaciated. The relative sea-level history is uncertain, but neither the relative sea-level lowering recently proposed by the ICE-5G glacio-isostatic model, nor the or the empirically-derived lowering of 110-120 m on outer continental shelves would suggest emergence of Flemish Cap (minimum depth $126 \mathrm{~m}$ ). With substrates that range from boulder-strewn bedrock to coarse sand, coupled with ice-free conditions, Flemish Cap may have been a glacial refugium for plant and animal species.

\section{Acknowledgements}

I thank Brian Todd and Patrick Potter for constructive criticism of early drafts of the paper. R. Drummond (University of Toronto) supplied ICE-5G relative sealevel predictions for Flemish Cap. This is a contribution to GSC Project J-27 (Paleo-evironmental Records of Climate Change, leader S. Wolfe), to the Atlantic Canada Glacier Ice Dynamics Project (leader J. Gosse) and to IGCP-464 (Continental Shelves during the last glacial cycle, leaders F. L. Chiocci and A. Chivas). This is Geological Survey of Canada Contribution 2004344.

\section{References}

BELL, T., D. G. E. LIVERMAN, M. BATTERSON, and K. SHEPPARD, 2001. Late Wisconsinan stratigraphy and chronology of southern St. George's Bay, Newfoundland: a re-appraisal. Can. J. Earth Sci., 38: 851-869.

BONIFAY, D., and D. J. W. PIPER. 1988. Probable late Wisconsinan ice margin on the upper continental slope off St. Pierre Bank, eastern Canada. Can. J. Earth Sci., 25: 853-865.

BOUSEFIELD, E. L., and M. L. H. THOMAS. 1975. Postglacial distribution of littoral marine invertebrates in the Canadian Atlantic region. In: Environmental Change in the Maritimes. J.G. Ogden, III and M.J. Harvey, (eds.), pp. 47-60. Nova Scotian Institute of Science, Halifax.

CUMMING, E. H., A. E. AKSU, and P. J. MUDIE. 1992. Late Quaternary glacial and sedimentary history of Bonavista Bay, northeast Newfoundland. Can. J. Earth Sci., 29: 222-235.

DYKE, A. S., and V. K. PREST. 1987a. Late Wisconsinan and Holocene history of the Laurentide Ice Sheet. Géog. Phys. et Quat., 41: 237-263.

1987b. Late Wisconsinan and Holocene retreat of the Laurentide Ice Sheet. Geological Survey of Canada, Map 1702A, scale 1:5000 000.

DYKE, A. S., J. T. ANDREWS, P. U. CLARK, J. H. ENGLAND, G. H. MILLER, J. SHAW, and J. J. VEILLETTE. 2002. The Laurentide and Innuitian ice sheets during the last glacial maximum. Quat. Sci. Rev., 21: 9-31

JOSENHANS, H. W., and G. B. J. FADER. 1989. A comparison of models of glacial sedimentation along the eastern Canadian margin. Mar Geol., 85: 273-300.

JOSENHANS, H. W., J. ZEVENHUIZEN, and R. A. KLASSEN. 1986. The Quaternary Geology of the Labrador Shelf. Can. J. Earth Sci., 23: 1190-1213.

JOSENHANS, H., and S. LEHMAN. 1999. Quaternary 
stratigraphy and glacial history of the Gulf of St. Lawrence, Canada. Can. J. Earth Sci., 36: 1327-1345.

KING, L. H., and G. B. J. FADER. 1990. Late Wisconsinan ice sheet margins of the Laurentian Channel. Abstract, The Geological Society of America, Northeastern Section, $25^{\text {th }}$ annual meeting, March 1990.

KING, L. H., B. MACLEAN, and G. B. J. FADER. 1974. Unconformities on the Scotian Shelf. Can. J. Earth Sci., 11: 89-100.

KING, L. H., G.B. FADER, W. H. POOLE, and R. K. WANLESS. 1985. Geological setting and age of the Flemish Cap granodiorite, east of the Grand Banks of Newfoundland. Can. J. Earth Sci., 22: 1286-1298.

LEBUIS, J., and P. P. DAVID. 1977. La stratigraphie et les événements du Quaternaire de la partie de la Gaspésie, Quebec. Géog. Phys. et Quat., 31: 275-296.

LIVERMAN, D., and T. BELL 1996. Late Quaternary glacial and glaciomarine sediments in Southern St. George's Bay. In: Current research (1996), Newfoundland Department of Natural Resources, Geological Survey, Report 96-1, p. 29-40.

LOCAT, J. 1977. L'émersion des terres dans la région de Baie-des-Sables/Trois-Pistoles, Québec. Géog. Phys. et Quat., 31: 297-306.

MIX, A. C., E. BARD, and R. SCHNEIDER. 2001. Environmental processes of the Ice Age, oceans, glaciers (EPILOG). Quat. Sci. Rev., 20: 627-657.

MOSHER, D. C., D. J. W. PIPER, G. V. VILKS, A. E. AKSU, and G. B. J. FADER. 1989. Evidence for Wisconsinan glaciations in the Verrill Canyon area, Scotian Slope. Quat. Res., 31: 27-40.

PELTIER, W. R. 2002a. Global glacial isostatic adjustment: palaeogeodetic and space-geodetic tests of the ICE-4G (VM2) model. J. Quat. Sci., 17: 491-510.

2002b. On eustatic sea level history: Last Glacial Maximum to Holocene. Quat. Sci. Rev., 21: 377-396 2004. Global Glacial Isostasy and the Surface of the Ice-Age Earth: The ICE-5G (VM2) Model and GRACE. Ann. Rev. Earth Plan. Sci., 31: 111-149.

PIPER, D. J. W., and D. C. CAMPBELL. In press. Quaternary geology of Flemish Pass and its application to geohazard evaluation for hydrocarbon development. Geological Association of Canada Special Paper.

PIPER, D. J. W., and A. MACDONALD. 2001. Timing, position of late Wisconsinan ice margins on the upper slope seaward of Laurentian Channel. Géog. Phys. et Quat., 55: 131-140.

RODRIGUES, C. G., J. A.. CEMAN, and G. VILKS. 1993. Late Quaternary paleoceanography of the deep and intermediate water masses off Gaspé Peninsula, Gulf of St. Lawrence: foraminiferal evidence. Can. J. Earth Sci., 30: $1390-1403$.

SHAW, J. 2003. Submarine moraines in Newfoundland coastal waters: implications for the deglaciation of Newfoundland and adjacent areas. Quat. Int., 99-100: 115-134.

SHAW, J., and R. C. COURTNEY. 2004. A digital elevation model of Atlantic Canada. Geological Survey of Canada Open File 4634.

SHAW, J., and D. L. FORBES. 1995. The postglacial relative sea-level lowstand in Newfoundland. Can. J. Earth Sci., 32: $1308-1330$.

SHAW, J., D. J. W. PIPER, G. B. J. FADER, B. J. TODD, T., BELL, M. J. BATTERSON, and D. G. E. LIVERMAN. 2006. A conceptual model of the deglaciation of Atlantic Canada. Quat. Sci. Rev., 25: 2059-2081.

SHAW, J., D. R. GRANT, J.-P. GUILBAULT, T. W. ANDERSON, and D. R. PARROTT. 2000. Submarine and onshore end moraines in southern Newfoundland: implications for the history of late Wisconsinan ice retreat. Boreas, 29: 295-314.

SHAW, J., P. GAREAU, and R. C. COURTNEY. 2002: Paleogeography of Atlantic Canada 13-0 kyr. Quat. Sci. Rev., 21: 1861-1878.

SHRIVASTAVA, S. P. and J. VERHOEF. 1992. Evolution of Mesozoic sedimentary basins around the North Central Atlantic: a preliminary plate kinematic solution. In: Basins on the Atlantic Seaboard: J. Parnell (ed.), Petroleum Geology, Sedimentology and Basin Evolution. Geological Society Special Publication No. 62: 397-420.

SHRIVASTAVA, S. P., J.-C. SIBUET, S. CANDE, W. R. ROEST, and I. D. REID. 2000. Magnetic evidence for slow seafloor spreading during the formation of the Newfoundland and Iberian margins. Earth. Plan. Sci. Let., 182: $1-76$.

TODD, B. J., and I. REID. 1989. The continent-ocean boundary south of Flemish Cap: constraints from seismic refraction and gravity. Can. J. Earth Sci., 26: 1392-1407.

WARREN, J. S. 1976. The morphology of two transverse channels on the Northeast Newfoundland Shelf. Mar. Sed., 12: 19-32. 